\title{
Sedimentation Management of Man-Made Water for Restoring the Quality of the River Resource
}

\author{
Oleksiy Nazarenko1, Oleksandr Ryabenko², Valeriy Bakhtin1, Iryna Nazarenko1, \\ Iryna Ovchinnykova ${ }^{1}$
}

${ }^{1}$ Zaporizhzhia National University, Zaporizhzhya, Ukraine

${ }^{2}$ National University of Water and Environmental Engineering, Rivne, Ukraine

Email: alexnazar75.an@gmail.com

How to cite this paper: Nazarenko, O., Ryabenko, O., Bakhtin, V., Nazarenko, I., \& Ovchinnykova, I. (2019). Sedimentation Management of Man-Made Water for Restoring the Quality of the River Resource. Journal of Geoscience and Environment Protection, 7, 327-337.

https://doi.org/10.4236/gep.2019.78022

Received: June 10, 2019

Accepted: August 26, 2019

Published: August 29, 2019

Copyright $\odot 2019$ by author(s) and Scientific Research Publishing Inc. This work is licensed under the Creative Commons Attribution International License (CC BY 4.0).

http://creativecommons.org/licenses/by/4.0/

\begin{abstract}
Research of water resources restoration of natural Dnieper river and man-made nature was carried out. The studies of water quality at working and peak operating modes of production cooling equipment were carried out. The conditions for the supersaturation of poorly soluble salts of the basin $\left(\mathrm{ns}_{\mathrm{CaCO}_{3}}=72.34 ; \mathrm{ns}_{\mathrm{CaSO}_{4}}=12.54\right)$ and accumulation of sediments of the reservoir are determined. The gravity tools for the restoration of water resources are proposed. A criterion equation for recharge the circulating system at peak mode was obtained. The granulometric potential of waste sediments at environmental feasibility is analyzed. The research involved supercritical temperature modes, taking into account precipitation hyperthermia. In the process of conducting a hydrological study, an evolutionary equation sediment model has been developed. The calculations of the technological flow capacity limits by of $125 \mathrm{~W} / \mathrm{m}^{2}$ due to turbidity $(750 \mathrm{mg} / \mathrm{l})$ and hardness (up to $12 \mathrm{mg}$ ekv per liter) of water resources are obtained. Mechanical sedimentation of the water stream increasing the energy potential up to $275 \mathrm{~W} / \mathrm{m}^{2}$ was determined. The use of chemical agents (ozone) as a combined treatment increasing the flow potential up to $650 \mathrm{~W} / \mathrm{m}^{2}$ is achieved. The application of technical way to natural water improving power to $975 \mathrm{~W} / \mathrm{m}^{2}$ is received. Erosion of the bottom of the basin reduces the hydrological potential due to the unfinished state of biodegradation of sediments. The hydrological characteristics of the stream at a distance of $3000 \mathrm{~m}$ with characteristic technogenic inclusions were obtained. The study was conducted at natural Dnieper river and laboratory conditions with chemical catalyst and mechanical activator.
\end{abstract}

\section{Keywords}

Water Basin, Precipitation Hyperthermia, Sedimentation, Circulating System, Hydrological Characteristics 


\section{Introduction}

The urgency of the current study is due to accidental changes in the quality of water resources, especially in man-made regions to understand the degree of water crisis.

The Dnipro River extends from the Middle Russian Plain and runs over 15 industrial cities and more than 1000 farms (Nazarenko, 2018) that meet the needs of drinking water.

It is a weight factor in production and vital to agriculture, transport, tourism and now the socio-economic development of the country. Industrial waste discharges, sewage discharge by urban agglomerations and agricultural waste directly lead to pollution of the Dnieper (Horppila, 2019). Increasing the level of concentration of certain pollutants pays attention to the public and may cause a health hazard (Drozdova, 2004). Thus, the necessity of integral management of the quality of water sources of wastewater treatment plants becomes essential. Real output data are basically huge; this means that they are not normally distributed, often collinear or autocorrelated, including nonstationary leaks (Markert et al., 2003). For this reason, multi-dimensional methods are used, such as analysis of the main components, cluster analysis, factor analysis (Syvitski et al., 2019). The analysis of the underlying factors is a data analysis tool, which is usually used to reduce the number of variables of a large number of interrelated Streamflow variables (Schertzinger et al., 2019). The program calculates an uncorrected set of variables. These factors are arranged so that the first few retain most of the variation present in all of the output variables. In a cluster analysis, objects are grouped based on similarities in the class and differences between different classes (Elgueta et al., 2019).

After the number of clusters is set as the input and initialized clusters of the centroid, observations are added iteratively to the most similar cluster, whose centroid is then recalculated until all observation is grouped (Xu et al., 2019).

Recovery steps are considered in this scientific work and are offered to environmentalists. Indicator of community development (Greco et al., 2013)-supplies the restored water for river basin by a complex algorithm.

Exceeding the high-quality sediment morphology leads to precipitation and accumulation of sediment and reduction of hydro-energy potential of rivers, especially important for the southern regions.

\section{Experimental Part}

Modern water supply does not plan disappearance of natural rivers, but in the event of global warming, drought can become a natural phenomenon.

In the research part the simulation modeling technogenic scenarios of community development was performed. To obtain a mathematical model, the squares method is used.

This analysis emphasizes the expediency of restoring the water to recharge the 
river basin (Epoyan et al., 2018). Fixing online data quality resources reduces overhead. Implementation of a flexible system approach for monitoring the quality of sewage waters with local sedimentation (salt content from 700 to 280 $\mathrm{mg}$ per litr) in a recreational lake creates for the reservoir. The management of the term of recovery water from 25 minutes (conditional clean liquid) to 150 minutes (conditional dirty liquid) provides the opportunity to use technology during the calendar year.

In this research, the following tools were used: a portable Gestovsky spool for measuring water flow, an IP 67 depth gauge, a water quality test sampler, a turbidity sensor for MSKDZ, a TDS3 saltmeter (Kathryn et al., 2019). For the formation of hydrological data, intrinsic measurements were used. Mathematical modeling was carried out by hydrological parameters.

\section{Research of Energy Saving of Reversible Water Supply System}

To ensure the performance of the water supply system of the sinter plant at ambient temperatures during the transitional season $\left(8^{\circ} \mathrm{C}\right)$ and summer season $\left(32^{\circ} \mathrm{C}\right)\left(X_{1}\right)$ and the hardness of the surface water $\left(X_{2}\right)(2.5$ - $3.6 \mathrm{mg}$-ekv per liter), which is actual for the southern rivers, requires fresh water recharge. Determination of the optimum quantity of supply $(Y)$, use the central orthogonal compositional arrangement of 2 orders [5].

\subsection{Calculation of Recharge of Water System}

The regression equation is obtained:

$$
Y=5.092785-0.28167 X_{1}+1.22325 X_{2}-0.009 H_{1}^{2}-0.7265 X_{2}^{2}-0.04375 X_{1} X_{2} .
$$

Under the best climatic conditions $\left(8^{\circ} \mathrm{C}\right)$, the factory can save till $890 \mathrm{~m}^{3}$ water per hour. Every change of the conditions of water consumption (tense working conditions, lack of control facilities, lack of dispatching) will save 272; 450; 1162 $\mathrm{m}^{3}$ per hour. Water-chemical modes of enterprise are shown in Table 1.

The proposed modes of operation include the need to control the indicator parameters to ensure the work process. Possibility using of re-water at the enterprise (mode 2, 5), if necessary, local recycling increases the coefficient of evaporation of the system.

The system's organicity (modes $1,3,4$ ) (Table 1 ) is presented for reliability of direct-flow water supply (Konovets et al., 2013). In the case of reverse water supply [7] (turbulence, evaporation, and steam power), the mode 6 become more progressive. Reserves of resource and energy saving can be found in industrial waste water from enterprises. In the necessary case, the return and recovery of wastewater is used by a cavitation device with a 6-degree angle to accelerate the process. The study of the quality of re-water (Pope et al., 2016) and the possibility of accumulation of sediment on the reservoir has been performed (Figure 1). 


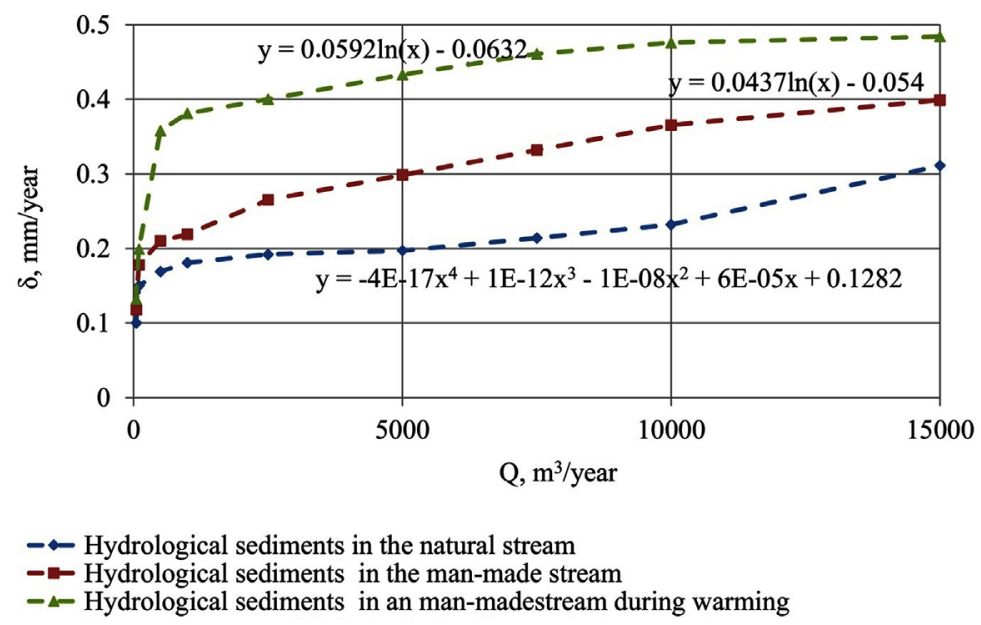

Figure 1. Speed of hydrological sediments formation.

Table 1. Water-chemical modes of production.

\begin{tabular}{ccccc}
\hline № $\Pi / \Pi$ & $\begin{array}{c}\text { Water hardness, } \\
\text { mg-eqv per liter }\end{array}$ & $\begin{array}{c}\text { Water alkalinity, } \\
\text { mg-eqv per liter }\end{array}$ & $\begin{array}{c}\text { Water } \\
\text { temperature, }{ }^{\circ} \mathrm{C}\end{array}$ & $\begin{array}{c}\text { Coefficient of } \\
\text { evaporation acceptable }\end{array}$ \\
\hline 1 & 4.5 & 4.5 & 40 & 1.516 \\
2 & 6.6 & 6 & 55 & 1.105 \\
3 & 3 & 3 & 25 & 1.99 \\
4 & 2 & 2 & 15 & 2.35 \\
5 & 12 & 3.5 & 40 & 1.53 \\
6 & 8.5 & 2.8 & 52 & 1.47 \\
\hline
\end{tabular}

\subsection{Research of the Amount of Hydrological Sediments in Different Streams}

The conducted researches of discharges of sewage in the interval of $50 \ldots 15,000$ $\mathrm{m}^{3}$ per hour have shown an increase in sediment from 0.11 up to $0.32 \mathrm{~mm}$ per year in an anthropogenic stream. In summer months it is possible to accelerate the dynamics of sedimentation of $0.12 \ldots 0.38 \mathrm{~mm}$ per year at $500 \mathrm{~m}^{3} /$ hour. Calculations of concentration supersaturation suggest the solubility product calcium and magnesium in the production mixture to the multiplicity of supersaturation $\mathrm{ns}_{\mathrm{CACO} 3}=72.34 ; \mathrm{ns}_{\mathrm{CASO} 4}=12.54 ; \mathrm{ns}_{\mathrm{MgOH}}=415.87$. With increasing flow up to $\mathrm{Q}=15,000 \mathrm{~m}^{3} / \mathrm{h}$, a relative stabilization of technogenic sedimentation going up to $0.14 \mathrm{~mm} /$ year occurs. Similar experiments on natural water show $0.12 \mathrm{~mm}$ per year of sediment at $50 \mathrm{~m}^{3} /$ hour of flow power. Similar results indicate the need for turbulence of the environment to accelerate the recovery of the resource. The research was conducted in field conditions with the receiving data on bathymetric sensors located in the Dnieper River.

The results of the research (Figure 1) indicate the heterogeneity of scenarios for managing natural resources. The lower blue curve shows the natural landscape, the red trajectory of emissions indicates a $22 \%$ increase in sediment due to physical and chemical transformations of mixtures (Parente \& Pepe, 2018). The 
upper curve (green) shows an increase in sediment by $11 \%$ due to hyperthermia (Zhao et al., 2019). The natural data are derived from bathymetric sediment gauges in the characteristic water section crossings. Simulation gives a picture of anthropogenic impact on the intersections of the basin and the place of accumulation of the raw material component for urban development [8] [9]. The phenomenon of sedimentation, which was investigated under real conditions, is presented in Figure 2. The hydrological toolkit for fixing real data on-line has been applied and patterns of morphological sediment transport have been revealed (Cherniuk et al., 2017) (Figure 3). The study was the basis for the development of the software "Bathymetry", for modeling the type of reservoir bed in geometric sections to determine the productivity of rivers in conditions of hyperthermia.

\subsection{Determination of the Power of the Recovered Stream}

The results of the program indicate that in the operational transfer of sediment data in characteristic sections there are places of interconnection using factors that consistently develop the evolution of the river model. This simulation is useful for the formation of natural barriers to spring floods and the creation of inventory of building resources (Semenov, 2011). The study of the determination of the capacity of the reservoir flows has been performed, to assess the generating potential. Practice shows that technogenic contaminated streams in sections $(2,3)$ (Figure 2) have low energy potential (about $1.72 \mathrm{~W} / \mathrm{m}^{2}$ ). The creation of favorable conditions locally at the enterprise helps to get the mode of $23 \ldots 115 \mathrm{~W} / \mathrm{m}^{2}$. The use of cavitation sedimentation for recharge allows to increase the potential to $935 \mathrm{~W} / \mathrm{m}^{2}$ of water surface. Control of the completion of decomposition of low soluble compounds is relevant for obtaining objective information on the state of the river (Jorgensen, 2011). Creation of recreational lakes is important for obtaining the correct background concentration at a control distance of $150 \ldots 400 \mathrm{~m}$.

Technogenic environment of the pollutant complicates the process of water recovery, increased operating costs. The power flow index is:

$$
\omega=\frac{\rho \cdot g \cdot \frac{4}{5} \cdot Q \cdot \frac{5}{7} \cdot S}{B},
$$

where $\rho$-density of water $\left(\mathrm{kg} / \mathrm{m}^{3}\right)$;

$g$-acceleration of free fall, $\mathrm{m}^{2} / \mathrm{s}$;

$Q$-water flow $\left(\mathrm{m}^{3} / \mathrm{s}\right)$;

$S$-surface area of water, $\mathrm{m}^{2}$;

$B$-flow width, m.

The study of the accumulation of roughly dispersed sediment to prevent flooding was studied at a distance of 3000 meters at a flow rate of up to $500 \mathrm{~m}^{3} / \mathrm{s}$. (Figure 2). It was found that the flow is characterized by peaks of dynamic pressure (preservation of predominantly rough sediments) and localized coastal erosion (predominantly precipitated), interspersed with morphologically stable sediments below the current (Table 2). 


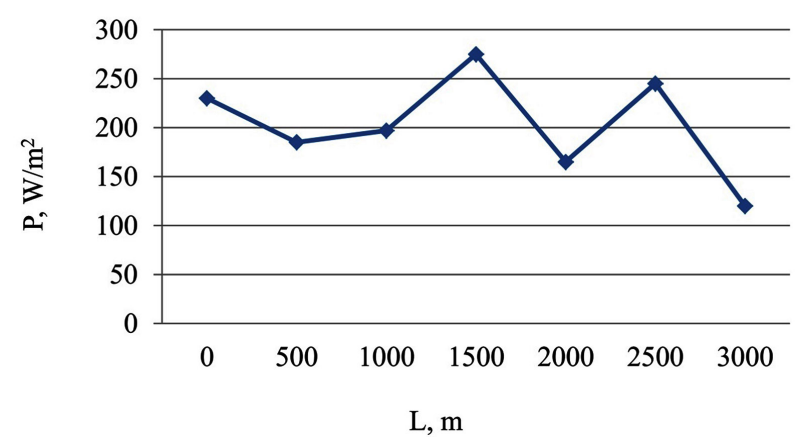

Figure 2. Flow capacity in man-made sections of the river.

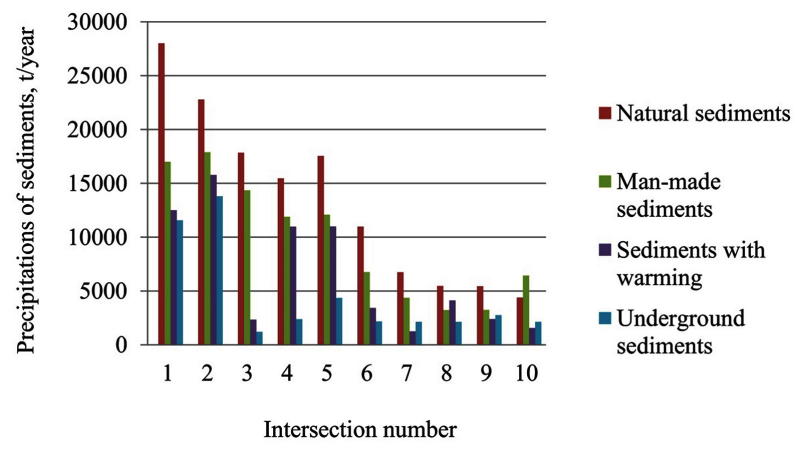

Figure 3. Annual values of precipitation at the intersections of the reservoir.

Table 2. The capacity of the water flow through the intersections.

\begin{tabular}{ccccc}
\hline $\begin{array}{c}\text { Intersection } \\
\text { number }\end{array}$ & $\begin{array}{c}\text { Capacity, } \\
\mathrm{W} / \mathrm{m}^{2}\end{array}$ & $\begin{array}{c}\text { Water flow, } \\
\mathrm{m}^{3} / \mathrm{s}\end{array}$ & $\begin{array}{c}\text { Intersection area, } \\
\mathrm{m}^{2}\end{array}$ & $\begin{array}{c}\text { Thickness of } \\
\text { sediments, } \mathrm{mm}\end{array}$ \\
\hline 1 & 231 & 451 & 148 & 23 \\
2 & 186 & 457 & 212 & 57 \\
3 & 197 & 483 & 203 & 48 \\
4 & 271 & 438 & 241 & 31 \\
5 & 168 & 471 & 201 & 69 \\
6 & 248 & 432 & 176 & 49 \\
7 & 138 & 420 & 193 & 76 \\
\hline
\end{tabular}

Investigations are conducted in the characteristic cross sections with high concentrations of the pollutant. Reducing power in the 2nd and 3rd sections indicates the attraction of a concentrated man-made stream. The stream needs mixing to sediment sedimentation. There is an active process of satiation of low-soluble salts, as a result of which the precipitate falls and the sensors transmit the model of sediment.

The results of calculating geomorphic energy should be taken into account hourly in case of discharges of sewage in sections (Hosocava et al., 1999). Losses up to $80 \%$ of the power at a distance of 500 meters and $105 \%$ at a distance of 200 meters distance indicate anthropogenic applications (Figure 3). The mixture requires dispersion in the buffer volume of the river at a distance of $150 \ldots 200$ 
meters of water flow. Reducing the concentration of components to the background concentration occurs depending on additional flows or groundwater occurs up to 300 meters of water flow.

The results may be included in Geographic Information Systems (GIS) to determine the stability of processes of geomorphic change (Shypulin, 2010), resource concentration, and decision-making on the basin (Nazarenko \& Bichenko, 2018).

Sediment control measures may include: vegetation filtering strips (VFS), local sediment basins (LBO) and cavitation fall structures (FCSs). Figure 4 shows the performance of deposition by various control measures. The results showed an increase of efficiency of $70 \%$ when using all three events together (manmade deposition of the RFU, deposition with WBW warming and precipitation of cavitational PCBs).

In the sections of the reservoir, precipitation occurs as a result of an increase in groundwater, till 4200 tons/year. Dynamic deposition indicates a short-term trend of morphological changes due to the imbalance of the precipitate. The result is a tendency for excessive erosion and accumulation of deposition. When using averaged parameters, the tool offers averaged results.

The results of the calculations show that the tendency of natural deposition is not linear, but depends on the product of solubility of insoluble salts of calcium and magnesium. The increasing nature of sediments has intersections that come in contact with industrial communications. Ordering can provide the integration of results into the "Water Circulation" complex. The rate of sediments can be controlled and plan the annual amount of sediment. According to calculations, the cavitational-centrifugal precipitate releases flow efficiency up to $935 \mathrm{~W} / \mathrm{m}^{2}$. Calculations of the critical power of the mixture of flow confirm the evaluation of the completion of the sedimentation process.

The local technogenic environment adds the geological parameters of the bed to the equation:

$$
(1-\lambda) B \frac{\partial Z}{\partial t}+\frac{\partial G}{\partial x}+\frac{\partial \varepsilon_{0}}{\partial \omega}
$$

where $\lambda$-porosity of the bed;

$B$-width of water surface, $\mathrm{m}$;

$Z$ - geodetic height of the bed, $\mathrm{m}$;

$t$-cycle duration, hours;

$G$-speed of transportation of deposits, $\mathrm{m}^{3} / \mathrm{s}$;

$x$-distance from man-made issue along the flow, $\mathrm{m}$;

$\varepsilon_{0}$-sediment porosity, $\mathrm{m}^{2} / \mathrm{s}$;

$\omega$-soil permeability, $\mathrm{m}^{3} / \mathrm{s}$.

Integration of scientific principles into the local Transferblock network for visualizing work risks and formatting the Ecoreact solution to preserve the morphometric conditions of the reservoir with hyperthermia.

Investigation of the phenomena of controlled cavitation is relevant for urban planning and prevention of anthropogenic phenomena (Figure 4 and Figure 5). 


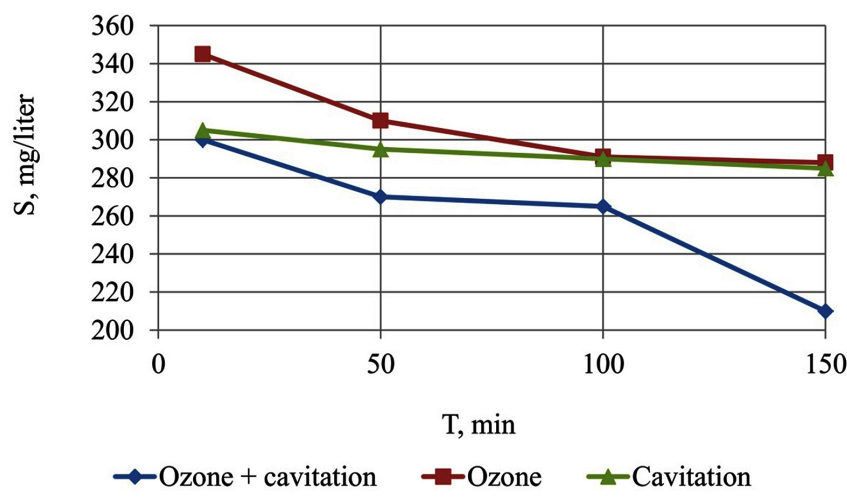

Figure 4. Reduction of the salt content (S) of conditionally clean liquid at different treatment modes $(\mathrm{T})$.

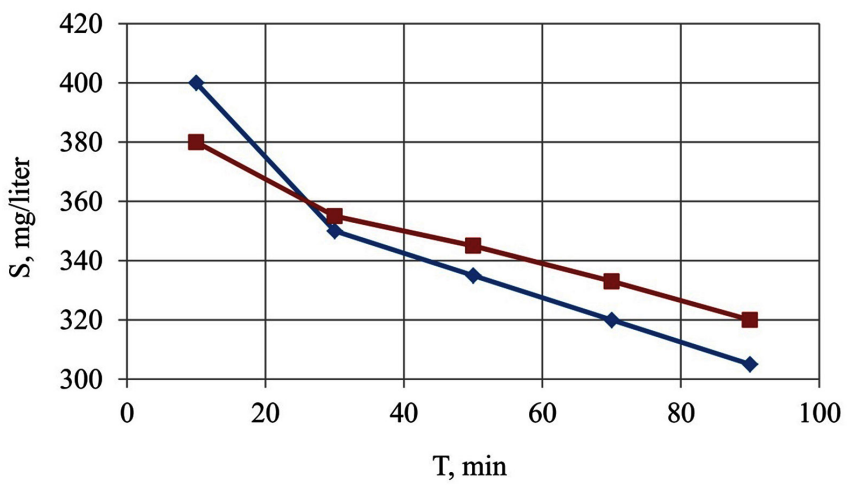

$\leadsto$ Ozone + cavitation, $515 \mathrm{kPa} \leftrightharpoons$ Ozone + cavitation, $275 \mathrm{kPa}$

Figure 5. Reduction of salt content (S) at different pressures and ozone-cavitational treatment $(\mathrm{T})$.

Bathymetric studies project the duration of sewage treatment taking into account the background concentration of components in the reservoir. In the case of inappropriate quality, the system will revert to the flow and determine the number of recovery operations and the duration of the process. The positive effect of research is observed on Figure 5. The energy consumption of the laboratory installation is $5 \mathrm{~kW}$, the productivity is $70 \mathrm{~m}^{3} /$ hour.

Modeling of the strategic volume of reservoirs in the context of ecological restoration of reservoirs is executed. The choice of operational factors is related to the simulations of the useful volume:

- man-made load;

- $50 \%$ of man-made load;

- climatic warming with 50\% load.

The issue of the duration and cyclicality of the process arises for the development of production plans. In the course of the study, the conditionally pure environment was used $\left(\mathrm{Q}=5500 \mathrm{~m}^{3} /\right.$ hour, $\mathrm{P}_{3}=65 \mathrm{~m}^{3} /$ hour, $\mathrm{ns}_{\mathrm{CACO} 3}=56,465$; $\left.\mathrm{ns}_{\mathrm{CASO} 4}=2.667 ; \mathrm{ns}_{\mathrm{MgOH}}=388.77\right)$ and conditional dirty liquid $\left(\mathrm{Q}=5500 \mathrm{~m}^{3} / \mathrm{hr}\right.$, $\left.\mathrm{P}_{3}=121 \mathrm{~m}^{3} / \mathrm{hr}, \mathrm{ns}_{\mathrm{CACO} 3}=122.83, \mathrm{~ns}_{\mathrm{CASO} 4}=4232, \mathrm{~ns}_{\mathrm{MgOH}}=1241.22\right)$. The results 
shows when cavitation precipitation, the salt content decreases in conditionally clean liqiud from 305 to $282 \mathrm{mg} /$ liter (8\%) at 150 minute term (3 cycles). Adding ozone as a disinfectant improves the effect from 302 to $207 \mathrm{mg} / \mathrm{liter}$ (46\%) in 150 minutes. Temporary work of the installation in 1 cycle suggests reducing the amount of salt from 302 to $268 \mathrm{mg} / \mathrm{liter}$ (12\%). Addition of normalized pressure improves the process from 380 to $319 \mathrm{mg} / \mathrm{liter}$ at $275 \mathrm{kPa}$ at 90 minutes of experiment.

\section{Discussion of the Results of Restoration Hydropower Capacity of the River}

The proposed integrated water pool management shall provide operational information from indicator changes of the water environment quality using man-made mixtures. In the southern regions, where the issue of the disappearance of reservoirs is particularly severe, the excess of the background concentration of the buffer volume causes a reciprocal reaction of the biocenosis, even to the extinction of all species.

The proposed bathymetric sensors will transmit the operational data of the excess of the solvent content of the pollutant. Application of cavitation sedimentation or combined ozone treatment solution will accelerate the processes of recovery of the resource. The limitations of technology implementation relate to the use of bathymetric sensors and rapid response systems. The creation jobs in regional ecological services are necessary for correction of water balance of a river and integration of current data in the all-Ukrainian base.

The development of hydrological modeling is promising in preventing floods and reducing the effects of arid phenomena for many water consumers.

\section{Conclusion}

The research of the regional variable soil infiltration is proposed. The paper allows predicting the level of soil moisture and yields of the districts; reducing the saltwater content of the recovered water by $8 \%$ at cavitation treatment, by $17 \%$ at ozonation, by $46 \%$ at the combined processing; reducing sulfur content of conventionally dirty liquid from 400 to $305 \mathrm{mg} /$ liter at $\mathrm{P}=515 \mathrm{kPa}$ in 90 minutes of sedimentation, increasing to $31 \%$. This process allowed cleaning up the buffer volume of the river and increased the energy capacity to $263 \mathrm{~W}$ per $1 \mathrm{~m}^{2}$ of water surface. Due to bathymetric sensors, the time of grounding the bed and the operating modes of the water system were investigated: sand at 180 minutes of cleaning of an industrial waste water up to 11 minutes on natural water. The study of sediments formation in the technogenic liquid in peak mode from 0.31 to $0.48 \mathrm{~mm} /$ per year at $15,000 \mathrm{~m}^{3}$ per hour system is obtained.

\section{Conflicts of Interest}

The authors declare no conflicts of interest regarding the publication of this paper. 


\section{References}

Cherniuk, W. V., Riabenko, O. A., \& Ivaniv, V. V. (2017). Influence of Transit Water Flow Rate on Its Dispensation and on Flow throught Nozzles in Pressure Pipelines under Action of External Pressure. Journal of Civil Engineering, 12, 139-146. https://doi.org/10.1515/sspjce-2017-0030

Drozdova, H. H. (2004). Methodology for Determining the Cost-Effectiveness of Conservation of Nature (12 p.). Kyev: KHTU.

Elgueta, M., Astaburuaga, M., \& Hassan, A. (2019). Sediment Storage, Partial Transport, and the Evolution of an Experimental Gravel Bed under Changing Sediment Supply Regimes. Geomorphology, 330, 1-12. https://doi.org/10.1016/j.geomorph.2018.12.018

Epoyan, S. M., Yarkin, N. A., \& Sukhorukov, G. I. (2018). Corridor-Type Baffles Mixing Basin with Cross Porous Barriers. Nauka ta Progress Transportu, 73, 24-32.

https://doi.org/10.15802/stp2018/124428

Greco, R., Comegna, L., Damiano, E., Guida, A., Olivares, L., \& Picarelli, L. (2013). Hydrological Modelling of a Slope Covered with Shallow Pyroclastic Deposits from Field Monitoring Data. Hydrology and Earth System Sciences, 17, 4001-4013. https://doi.org/10.5194/hess-17-4001-2013

Horppila, J. (2019). Sediment Nutrients, Ecological Status and Restoration of Lakes. Water Research, 160, 206-208. https://doi.org/10.1016/j.watres.2019.05.074

Hosocava, T., Ivasaki, M., \& Komatsubara, H. (1999). Kurita Handbook of Water Treatment (2nd ed., 499 p.). Tokyo: Water Industries Ltd.

Jorgensen, S. E. (2011). Handbook of Ecological Models Used in Ecosystem and Environmental Management (600 p.). Copenhagen: University Denmark, CRC Press.

Kathryn, L., Russell, G., Vietz, J., \& Fletcher, D. (2019). Urban Sediment Supply to Streams from Hillslope Sources. Science of the Total Environment, 653, 684-697. https://doi.org/10.1016/j.scitotenv.2018.10.374

Konovets, I., Kipris, L., Goncharov, M. et al. (2013). Ecological and Toxicological Assessment of the Pollution Lavels of Waterand Sediments of Ivivka River near the Airport Kyiv. Ribogospodarska Nauka, 2, 32-44. https://doi.org/10.15407/fsu2013.02.032

Markert, B. A., Breure, A. M., \& Zechmeister, H. G. (2003). Bioindicators and Biomonitors: Principles, Concepts and Application. Trace Metals and Other Contaminants in the Environment, 6, 15-25.

Nazarenko, O. M. (2018). Risk Management of Water Users of the Dnieper River (203 p.). Zaporizhia: STS Groop.

Nazarenko, O. M., \& Bichenko, K. O. (2018). System for Remote Monitoring of Coolant Parameters in Two-Pipe Heat Networks. Patent UA No. 123556, MPK, F17D5/02/2006. (In Ukrainian)

Parente, C., \& Pepe, M. (2018). Bathymetry from Worldview-3 Satellite Data Using Radiometric Band Ratio. Acta Polytechnica, 58, 109-117. https://doi.org/10.14311/AP.2018.58.0109

Pope, A., Scambos, T., Moussavi, M., Tedesco, M., Willis, M., Shean, D., \& Grigsby, S. (2016). Estimating Supraglacial Lake Depth in West Greenland Using Landsat 8 and Comparison with Other Multispectral Methods. The Cryosphere, 10, 15-27. https://doi.org/10.5194/tc-10-15-2016

Schertzinger, G., Zimmermann, S., \& Sures, B. (2019). Predicted Sediment Toxicity Downstream of Combined Sewer Overflows Corresponds with Effects Measured in Two Sediment Contact. Environmental Pollution, 248, 782-791. 
https://doi.org/10.1016/j.envpol.2019.02.079

Semenov, O. E. (2011). Introduction into Experimental Meteorology and Climatology of Sandstorms (187 p.). Almaty.

Shypulin, V. D. (2010). Basic Principles of Neo-Information Systems (337 p.). Kharkiv: Khnahkh.

Syvitski, J., Cohen, S., Miara, A., \& Best, J. (2019). River Temperature and the Thermal-Dynamic Transport of Sediment. Global and Planetary Change, 178, 168-183. https://doi.org/10.1016/j.gloplacha.2019.04.011

Xu, K., Samuel, J., Bentley, J., Day, W., \& Freeman, A. (2019). A Review of Sediment Diversion in the Mississippi River Deltaic Plain. Estuarine, Coastal and Shelf Science, 225, Article ID: 106241. https://doi.org/10.1016/j.ecss.2019.05.023

Zhao, L., Wang, R., Zhang, C., Yin, D., Yang, S., \& Huang, X. (2019). Geochemical Controls on the Distribution of Mercury and Methylmercury in Sediments of the Coastal East China Sea. Science of the Total Environment, 667, 133-141.

https://doi.org/10.1016/j.scitotenv.2019.02.334 